\title{
The influence of psychiatric screening in healthy populations selection: a new study and meta- analysis of functional 5-HTTLPR and rs25531 polymorphisms and anxiety-related personality traits
}

\author{
Alessandra Minelli ${ }^{1}$, Cristian Bonvicini ${ }^{1}$, Catia Scassellati ${ }^{1}$, Riccardo Sartori ${ }^{2}$ and Massimo Gennarelli ${ }^{1,3^{*}}$
}

\begin{abstract}
Background: A genetic liability for anxiety-related personality traits in healthy subjects has been associated with the functional serotonin transporter promoter polymorphism (5-HTTLPR), although the data are somewhat conflicting. Moreover, only one study has investigated the functional significance of the 5-HTTLPR/rs25531 haplotypes in relation to anxiety traits in healthy subjects. We tested whether the 5-HTTLPR polymorphism and the 5-HTTLPR/rs25531 haplotypes are linked to Harm Avoidance (HA) using an association study (STUDY I) and a metaanalytic approach (STUDY II).

Methods: STUDY I: A total of 287 unrelated Italian volunteers were screened for DSM-IV Axis I disorders and genotyped for the 5-HTTLPR and rs25531 (A/G) polymorphisms. Different functional haplotype combinations were also analyzed. STUDY II: A total of 44 studies were chosen for a meta-analysis of the putative association between 5-HTTLPR and anxiety-related personality traits.

Results: STUDY I: In the whole sample of 287 volunteers, we found that the SS genotype and S'S' haplotypes were associated with higher scores on HA. However, because the screening assessed by Mini-International Neuropsychiatric Interview (M.I.N.I.) showed the presence of 55 volunteers affected by depression or anxiety disorders, we analyzed the two groups ("disordered" and "healthy") separately. The data obtained did indeed confirm that in the "healthy" group, the significant effects of the SS genotype and S'S' haplotypes were lost, but they remained in the "disordered" group. STUDY II: The results of the 5-HTTLPR meta-analysis with anxiety-related traits in the whole sample confirmed the association of the SS genotype with higher anxiety-related traits scores in Caucasoids; however, when we analyzed only those studies that used structured psychiatric screening, no association was found.
\end{abstract}

Conclusions: This study demonstrates the relevance to perform analyses on personality traits only in DSM-IV axis I disorder-free subjects. Furthermore, we did not find an association between functional serotonin transporter gene polymorphisms and anxiety traits in healthy subjects screened through a structured psychiatric interview.

Keywords: Neuroticism Harm Avoidance, 5-HTTLPR, rs25531, meta-analysis

\section{Background}

Personality traits can be defined as individual qualities or characteristics that influence cognitions, emotions, and behaviors and lead to adaptive or maladaptive responses. Human personality is a multidimensional structure that is affected by both environmental and

\footnotetext{
* Correspondence: gennarelli@fatebenefratelli.it

'Genetic Unit, I.R.C.C.S. "San Giovanni di Dio" - Fatebenefratelli, Brescia, Italy Full list of author information is available at the end of the article
}

genetic factors. According to the literature, individual variation of the heritable component is estimated to account for $30-40 \%$ of the variance in personality traits [1]. To date, the most frequently studied candidate gene for personality traits has been the functional polymorphism 5-HTTLPR in the promoter region of the SLC6A4 gene, which encodes the serotonin transporter. This polymorphism results in a short $(\mathrm{S})$ and a long $(\mathrm{L})$ variant $[2,3]$. 
Functional studies of the activity of the SLC6A4 promoter in transfected cell lines, postmortem human brains, and lymphoblasts have confirmed that the $\mathrm{L}$ allele is associated with higher levels of transcriptional activity and influences the rate of serotonin uptake more than the $\mathrm{S}$ variant [4]. According to recent findings, the $S$ allele is associated with a less favorable response/resistance to pharmacological treatment [5-8] but also with central stress regulation [9-11].

Recently it has been critically discussed that the analysis of 5-HTTLPR is incomplete, because other polymorphisms have been found in the proximity of the Ins/Del locus, such as rs25531, rs25532, rs2020933, and a 17-bp variable tandem repeat in the second intron (STin2) $[4,12,13]$. In particular, rs25531, the polymorphism nearest 5-HTTLPR, results in an A to G substitution and has been shown to modulate the effect of 5-HTTLPR on transcriptional efficacy. Our recent work [8] reported evidence that the rs25531 polymorphism is located immediately outside of the 5-HTTLPR segment, resulting in the status of 5-HTTLPR and rs25531 as two independent polymorphisms. It has been reported that the $\mathrm{G}$ allele of rs25531 is in phase with the 5-HTTLPR long allele and mitigates transcriptional efficacy more than does the 5-HTTLPR short allele. Therefore, the modulation of 5-HTTLPR by rs25531 results in haplotypes with a high $\left(\mathrm{L}_{\mathrm{A}}\right)$ or low $\left(\mathrm{L}_{\mathrm{G}}\right.$, $\mathrm{S}_{\mathrm{A}}$ or $\mathrm{S}_{\mathrm{G}}$ ) transcriptional efficacy $[4,14]$.

The inventories mostly used in biological studies of personality are the NEO-Personality Inventory [15] and the Temperament and Character Inventory (TCI) [16]. Although NEO and TCI have relevant differences, they appear similar when evaluating anxiety traits such as Neuroticism (N) and Harm Avoidance (HA). Several studies have shown that $\mathrm{N}$ is highly related to $\mathrm{HA}[17,18]$, but there is evidence that $\mathrm{N}$ and HA may not be equivalent [19].

Since the first paper of Lesch [3] was published, a large number of studies have sought evidence of an association between the 5-HTTLPR polymorphism and anxietyrelated personality traits. Despite these investigations, the strength and nature of any association is still uncertain. Controvertible results were obtained using both the TCI and NEO scales. In addition, five meta-analyses [20-24] provided conflicting results. In 2003, Munafò [20] reported an association between the 5-HTTLPR polymorphism and avoidance traits, but this effect was no longer being significant when data from studies reporting allele frequencies not in Hardy-Weinberg equilibrium (HWE) and unpublished data were excluded. Two successive meta-analyses $[23,24]$ found an association between $\mathrm{N}$ and 5-HTTLPR, although no link with HA was observed. However, opposing data were reported in a different meta-analysis in 2005 [21]. Munafò et al. [21] concluded that the effect, if present, is small. More recently, the same authors [22] presented a more complete meta-analysis, which evidenced no association of 5-HTTLPR with HA and a significant association with $\mathrm{N}$; however, the association was lost due to high between-study heterogeneity in analyses conducted using the random effects model.

It is important to emphasize that these contrasting results may be explained by the inclusion of studies that recruited participants from psychiatric populations. Both Schinka and Sen's meta-analyses [23,24] included data from healthy and patients whereas the different Munafò's meta-analyses [20-22] explicitly excluded studies that recruited from psychiatric populations and, when both psychiatric and control samples were recruited, data from healthy controls only were included. Indeed, the personality traits of pathological people could be confounding factors. It has long been known that depression and anxiety disorders are associated with higher scores for anxiety-related traits [25-28]. In addition, a higher frequency of the $S$ allele was observed in depressed and anxious disorders patients [29]. Another relevant bias could be the inclusion of data from presumably healthy subjects without any psychological screening to exclude any DSM-IV axis I psychiatric disorders.

On the basis of these conflicting evidences we performed the following analyses: 1) STUDY I: an association study between the 5-HTTLPR and rs25531 and the relative estimated/phased haplotypes with anxiety personality traits measured using the self-rated TCI scale. The analyses were carried out in the whole sample of controls as well as in subjects without any DSM-IV axis I disorders screened by structured interviews; 2) STUDY II: meta-analyses of 5-HTTLPR and HA or $\mathrm{N}$ in controls and in screened samples.

STUDY 1: A new association study of 5-HTTLPR and 5-HTTLPR/rs25531 with HA

\section{Methods}

\section{Participants}

A total of 287 unrelated volunteers (age: $50.05 \pm 15.94$ years [mean $\pm \mathrm{SD}$ ]; range: 22 to 87 years; 117 males and 170 females) were recruited through a variety of sources, such as universities, newspaper advertisements, and elderly associations. The study protocol was approved by the Ethics Committee of Fatebenefratelli Hospital (San Giovanni di Dio, Brescia, Italy), and written informed consent was obtained from all the subjects. The subjects were screened for DSM-IV Axis I disorders through the Mini-International Neuropsychiatric Interview (M.I.N.I.) [30] and screened for any history of drug or alcohol abuse or dependence by expert psychologists. Personality traits were assessed by the Italian version of TCI, a 240item true-false self-report questionnaire [31]. Subjects who scored less than 27/30 on the Mini-Mental State Examination (M.M.S.E.) [32] were excluded from the study to avoid biases in the completion of the TCI. 


\section{Genotyping analyses of 5-HTTLPR and rs25531}

Isolation of DNA, genotyping of 5-HTTLPR and rs25531, as well as the classification of estimated phased haplotypes $\left(\mathrm{S}_{\mathrm{A}} \mathrm{S}_{\mathrm{A}}, \mathrm{S}_{\mathrm{G}} \mathrm{S}_{\mathrm{G}}, \mathrm{L}_{\mathrm{G}} \mathrm{S}_{\mathrm{A}}\right.$, and $\mathrm{L}_{\mathrm{G}} \mathrm{L}_{\mathrm{G}}$ as $\mathrm{S}^{\prime} \mathrm{S}^{\prime} ; \mathrm{L}_{\mathrm{A}} \mathrm{S}_{\mathrm{A}}$ and $L_{A} L_{G}$ as $L^{\prime} S^{\prime}$; and $L_{A} L_{A}$ as $L^{\prime} L^{\prime}$ ) were described in a study by Bonvicini [8]. We did not detect the $\mathrm{L}_{\mathrm{G}} \mathrm{L}_{\mathrm{G}}$ or $\mathrm{S}_{\mathrm{G}} \mathrm{S}_{\mathrm{G}}$ haplotypes in the genotyping analyses.

\section{Statistical analysis}

The association between TCI scores and 5-HTTLPR or 5 -HTTLPR/rs25531 was analyzed by analysis of variance, using the HA score as the dependent variable, genotypes and sex as independent variables, and age as a covariate (ANCOVA). The p-values have been corrected for multiple comparisons. All analyses were conducted using SPSS statistical software version 12.0 (SPSS Inc., Chicago, IL).

The association study showed a power $>80 \%$ by using the Quanto program version 1.2.4 with the following parameters: 5-HTTLPR $S$ and S'S' minor allele frequencies (MAFs) of $15 \%$ and $21 \%$, respectively, in a population of European origin; $\mathrm{p} \leq 0.05$; OR $\geq 1.6$; $\log$ additive mode of inheritance; and population risk $\geq 10 \%$.

\section{Results}

In the whole sample of 287 volunteers, the minor S allele frequency of the 5-HTTLPR polymorphism was 0.39; the genotype frequencies and HA (mean score +/ SD) of LL, LS, and SS were 0.37 (43.42 +/ - 17.14), 0.48 (42.55 +/$17.96)$ and $0.15(48.57+/-20.18)$, respectively (Table 1$)$. The genotype distributions were in $\operatorname{HWE}\left(\chi^{2}=0.05 ; \mathrm{p}=\right.$ 0.82 ). The results indicated a trend toward an association between 5-HTTLPR and anxiety-related scale for genotypes $(\mathrm{p}=0.06)$, and a significant effect was found when we considered the $\mathrm{L}$ allele as dominant $(\mathrm{p}=0.02)$. Concerning the analysis of the 5-HTTLPR/rs25531 the ANCOVA results showed an effect using a dominant $\mathrm{L}$ model (L'L' + L'S' vs. S'S' p = 0.05, Table 1).

Based on the assessment performed using M.I.N.I., the sample consisted of 229 (80\%) subjects without lifetime DSM-IV Axis I disorders (the "healthy" group) and 58 subjects $(20 \%)$ with these disorders (the "disordered" group). In the "disordered" group, 38 subjects had MDD, 2 had Panic Disorder, 22 had Generalized Anxiety Disorder, 6 had Dysthymia, 1 had Bipolar Disorder, 1 experienced alcohol abuse and 1 experienced substance abuse (the total number exceeds the number of subjects due to the presence of comorbidity). Because the literature has largely shown that people affected by unipolar major depression and anxiety disorders present homogeneous patterns of personality traits compared to other subjects [25-28,33-36], the 55 participants with depression and/or anxiety lifetime diagnosis were regrouped. The three subjects affected by Bipolar Disorder, experienced alcohol and substance abuse were consequently excluded.

Thus, to evaluate whether the results from the participants excluded by M.I.N.I. had influenced the previous analyses, we performed ANCOVA using the HA score as the dependent variable, groups ("healthy" $\mathrm{N}=229$, "disordered" $\mathrm{N}=55$ ), genotypes, and sex as independent variables, and age as a covariate for both 5-HTTLPR and estimated/phased haplotypes. The results indicated that, the disordered group showed significantly higher HA scores than healthy subjects $(F=46.72, p<0.0001)$. No association was found between 5-HTTLPR polymorphism and anxiety traits $(\mathrm{F}=1.34, \mathrm{p}=0.26)$, whereas a significant interaction was observed between the 5-HTTLPR genotype and groups $(\mathrm{F}=4.52, \mathrm{p}=$ $0.03)$. The same pattern was obtained when the SS genotype was compared to allele $\mathrm{L}$ carriers $(\mathrm{F}=4.41, \mathrm{p}=$ 0.04). Concerning the 5 -HTTLPR/rs25531, a significant interaction was detected with the dominant $\mathrm{L}$ model (L'L' + L'S' vs. S'S'; p = 0.02). In all analyses, no significant gender effect or interaction was obtained.

In the sample of subjects with no DSM-IV axis I disorders (healthy group), we performed an ANCOVA analysis to test the possible association between polymorphisms and HA. There was no significant association between HA and either the 5-HTTLPR or the 5-HTTLPR/rs25531 haplotypes (Table 1). Despite its small size, the disordered group revealed an association between HA and SS or S'S' homozygosity ( $\mathrm{p}=0.05$ and $\mathrm{p}=0.03$, respectively).

STUDY 2: Meta-analyses of 5-HTTLPR with anxiety traits

\section{Methods}

\section{Literature search}

To identify eligible studies for the meta-analysis, we performed a search through PubMed (at the National Library of Medicine) for all the available studies of the association between the serotonin transporter and anxiety personality traits conducted in healthy adults, using the following search terms: serotonin transporter polymorphism, serotonin transporter gene, 5-HTTLPR, Neuroticism, Harm Avoidance, anxiety, and personality. Once articles had been collected, bibliographies were manually searched for additional eligible studies.

\section{Inclusion criteria}

All association studies that have measured anxiety traits using any version of NEO (NEO-PI, NEO-PI-R, or NEO-FFI) or the TCI (or TPQ) in male and/or female participants of any ethnic origin were included. Only data from controls were included from studies in which psychiatric patients and control data were compared. Data that appeared in more than one published study 
Table 1 HA scores (Mean \pm Standard Deviation) of all participants, including screened healthy subjects and people excluded for depression and anxiety disorders, stratified according to the 5-HTTLPR and the 5-HTTLPR/rs25531 estimated/phased haplotypes

\begin{tabular}{|c|c|c|c|c|c|c|c|c|c|}
\hline \multirow[b]{2}{*}{$\begin{array}{c}\text { Genotype 5- } \\
\text { HTTLPR }\end{array}$} & \multicolumn{3}{|c|}{ All subjects (287) } & \multicolumn{3}{|c|}{ Healthy subjects (229) } & \multicolumn{3}{|c|}{ Disordered subjects ${ }^{b}(55)$} \\
\hline & $\begin{array}{c}N \text { (freq. } \\
\%)\end{array}$ & $\begin{array}{c}H A(\text { mean } \pm \\
S D)\end{array}$ & $\begin{array}{c}p \\
(A N C O V A)^{a}\end{array}$ & $\begin{array}{c}N \text { (freq. } \\
\%)\end{array}$ & $\begin{array}{l}H A(\text { mean } \pm \\
S D)\end{array}$ & $\begin{array}{c}p \\
(A N C O V A)^{a}\end{array}$ & $\begin{array}{c}N \text { (freq. } \\
\%)\end{array}$ & $\begin{array}{l}H A(\text { mean } \pm \\
S D)\end{array}$ & $\begin{array}{c}p \\
(A N C O V A)^{a}\end{array}$ \\
\hline $\mathrm{LL}$ & $107(0.37)$ & $43.42 \pm 17.14$ & $F=2.84$ & $93(0.41)$ & $41.63 \pm 15.66$ & $F=0.34$ & $13(0.24)$ & $57.14 \pm 21.73$ & $F=1.85$ \\
\hline LS & $138(0.48)$ & $42.55 \pm 17.96$ & $p=0.06$ & $109(0.48)$ & $39.08 \pm 16.72$ & $p=0.71$ & $27(0.49)$ & $56.19 \pm 16.88$ & $p=0.17$ \\
\hline SS & $42(0.15)$ & $48.57 \pm 20.18$ & & $27(0.11)$ & $37.25 \pm 12.11$ & & $15(0.27)$ & $68.95 \pm 15.11$ & \\
\hline \multicolumn{10}{|l|}{ Carriers } \\
\hline Carriers L & $245(0.85)$ & $42.93 \pm 17.57$ & $F=5.73$ & $202(0.89)$ & $40.25 \pm 16.25$ & $F=0.18$ & $40(0.73)$ & $56.50 \pm 18.32$ & $F=3.86$ \\
\hline vs SS & & & $p=0.02$ & & & $p=0.67$ & & & $p=0.05$ \\
\hline Carriers S & $180(0.63)$ & $43.95 \pm 18.62$ & $F=0.37$ & $136(0.59)$ & $38.72 \pm 15.89$ & $F=0.70$ & $42(0.76)$ & $60.75 \pm 17.24$ & $F=0.60$ \\
\hline vs LL & & & $p=0.54$ & & & $p=0.40$ & & & $p=0.44$ \\
\hline \multicolumn{10}{|c|}{ Phased Haplotype frequencies } \\
\hline$L_{A} L_{A}$ & $93(0.32)$ & $42.27 \pm 16.60$ & $F=2.00$ & $82(0.36)$ & $40.70 \pm 14.97$ & $F=0.59$ & $10(0.18)$ & $56.29 \pm 23.41$ & $F=1.14$ \\
\hline$L_{A} L_{G}$ & $14(0.05)$ & $51.02 \pm 19.28$ & $p=0.09$ & $11(0.05)$ & $48.57 \pm 19.55$ & $p=0.67$ & $3(0.05)$ & $60.00 \pm 18.73$ & $p=0.35$ \\
\hline$L_{A} S_{A}$ & $120(0.42)$ & $42.41 \pm 17.58$ & & $94(0.41)$ & $38.85 \pm 16.14$ & & $25(0.46)$ & $55.20 \pm 17.16$ & \\
\hline $\mathrm{L}_{G} \mathrm{~S}_{\mathrm{A}}$ & $18(0.06)$ & $43.49 \pm 20.82$ & & $15(0.07)$ & $40.57 \pm 20.58$ & & $2(0.04)$ & $68.57 \pm 4.04$ & \\
\hline $\mathrm{S}_{\mathrm{A}} \mathrm{S}_{\mathrm{A}}$ & $42(0.15)$ & $48.57 \pm 20.18$ & & $27(0.11)$ & $37.25 \pm 12.11$ & & $15(0.27)$ & $68.95 \pm 15.11$ & \\
\hline \multicolumn{10}{|c|}{ Clustered Phased Haplotype frequencies } \\
\hline$L^{\prime} L^{\prime}$ & $93(0.32)$ & $42.27 \pm 16.60$ & $F=2.12$ & $82(0.36)$ & $40.70 \pm 14.97$ & $F=0.04$ & $10(0.18)$ & $56.29 \pm 23.41$ & $F=2.50$ \\
\hline$L^{\prime} S^{\prime}$ & $134(0.47)$ & $43.30 \pm 17.88$ & $p=0.12$ & $105(0.46)$ & $39.86 \pm 16.69$ & $p=0.96$ & $28(0.51)$ & $55.71 \pm 17.03$ & $p=0.09$ \\
\hline$S^{\prime} S^{\prime}$ & $60(0.21)$ & $47.05 \pm 20.34$ & & $42(0.18)$ & $38.43 \pm 15.50$ & & $17(0.31)$ & $68.91 \pm 14.17$ & \\
\hline \multicolumn{10}{|c|}{ Carriers of Phased haplotypes } \\
\hline$\left(L^{\prime} L^{\prime}+L^{\prime} S^{\prime}\right)$ & $227(0.79)$ & $47.05 \pm 20.34$ & $F=3.92$ & $187(0.82)$ & $38.43 \pm 15.50$ & $F=0.08$ & $38(0.69)$ & $68.91 \pm 14.17$ & $F=5.15$ \\
\hline vs $\left(S^{\prime} S^{\prime}\right)$ & & & $p=0.05$ & & & $p=0.77$ & & & $p=0.03$ \\
\hline$\left(L^{\prime} S^{\prime}+S^{\prime} S^{\prime}\right)$ & $194(0.68)$ & $44.46 \pm 18.70$ & $F=1.47$ & $147(0.64)$ & $39.45 \pm 16.32$ & $F=0.04$ & $45(0.82)$ & $60.70 \pm 17.11$ & $F=0.81$ \\
\hline vs L'L' & & & $p=0.23$ & & & $p=0.85$ & & & $p=0.37$ \\
\hline
\end{tabular}

The ANCOVA results for the genotypes, clustered genotype, and carriers are included.

${ }^{a} \mathrm{HA}$ score as the dependent variable, genotype or clustered genotype and sex as independent variables, and age as a covariate.

${ }^{\mathrm{b}}$ Disordered group consisted of subjects with depression and anxiety disorders.

were included only once in the analyses. Papers not written in English [37] were excluded.

\section{Data extraction}

We recorded the number of participants, the mean of $\mathrm{N}$ and/or HA trait scores, and the standard deviation for each of the three genotype groups (LL, LS, SS) in each study included in our analysis. Furthermore, we extracted data regarding the male/female ratio, the mean age, the ethnic compositions of the sample, and the structured clinical interview used for screening. Genotype frequencies were used to calculate the HWE (program http://www.genemapping.cn). In cases where all or part of this information was not available in the publication, the authors were contacted by email.

\section{Statistical analyses}

The Review Manager was used to analyze data (RevMan Version 5.0.16; Copenhagen, The Nordic Cochrane Centre, The Cochrane Collaboration, 2008).
Firstly, data were analyzed with the fixed effects model in order to combine individual study effect sizes (Cohen's $d$ s) using inverse variance methods to generate a summary $d$ and 95\% confidence interval (CI). We analyzed a possible association by both comparing LL genotype versus carriers of the S allele and SS genotype versus carriers of the $\mathrm{L}$ allele. The significance of the pooled effect sizes was determined by the $Z$-test and the between-study heterogeneity was assessed using a $\chi^{2}$ test of goodness of fit and $\mathrm{I}^{2}$ statistic [38]. The significant $p$ value was set at 0.05 . In a fixed effects model, the fundamental assumption is that a single true effect size underlies all study results and that observed estimates vary only as a function of chance. The error term in a fixed effects model represents only within-study variation, and between-study variation is ignored. Where the results showed a significant effect in the presence of significant betweenstudy heterogeneity, a random effects model was utilized, with $d$ s pooled using the DerSimonian and Laird 
methods [39]. In contrast, a random effects model assumes that each study estimates different, yet related, true effects and that the distribution of the various effects is normally distributed around a mean effect size value. This model takes both within- and betweenstudy variation into account. When there is little heterogeneity, both models yield essentially identical results. When heterogeneity is extensive, however, the analyses will yield different estimates of the mean effect size, and the confidence intervals around the estimates will be different sizes. When there is heterogeneity across studies, the random effects model yields wider confidence intervals than the fixed effects model and is thus usually more conservative.

\section{Results}

A total of 50 studies [3,22,40-88] met our inclusion criteria; their features are shown in Table 2. Six studies were excluded from our analyses for significant deviation from HWE ( $\mathrm{p} \leq 0.05)[46,52,60,65,74,81]$, and one was excluded for excessive ethnic heterogeneity [56]. Furthermore, nine other studies $[50,62,63,67,68,71,76,78,86]$ were not included because the data regarding anxiety traits for each genotype and/or the data to test HWE were insufficient, and we were unable to obtain this kind of information from the authors.

Therefore, the meta-analysis used the results of 35 studies, including $7[41,49,55,59,69,84,85]$ that reported data for both inventories, 1 [83] that generated data on NEO on 2 different independent samples, and the data of present work; in total, 44 samples were available for analysis.

Because of ethnic differences in the 5-HTTLPR genotype distribution, the studies on Asian and Caucasoid populations were independently analyzed. When we conducted a comparison analysis between the LL genotype and S allele carriers in the Caucasoid population (Figure 1), no association was observed between 5-HTTLPR and HA ( $p=0.94)$,

Table 2 Characteristics of association studies eligible for inclusion

\begin{tabular}{|c|c|c|c|c|c|c|c|c|c|c|}
\hline Study & Year & Inventory $^{a}$ & $\mathrm{~N}$ & $\%$ Male & Mean Age & Ethnicity & HW equilibrium & $\mathrm{HW} \chi 2$ & HW p & Exclusion \\
\hline Lesch & 1996 & NEO & 505 & 92 & 37.6 & 94\% Caucasian & YES & 0.01 & 0.93 & \\
\hline Ebstein & 1997 & $\mathrm{TCl}$ & 121 & 55 & 29.7 & 74\% Caucasian & YES & 1.14 & 0.29 & \\
\hline Nakamura & 1997 & Both & 186 & 0 & 19.6 & Asian & YES & 1.15 & 0.28 & \\
\hline Mazzanti & 1998 & $\mathrm{TCl}$ & 215 & 85 & 35.5 & Caucasian & YES & 0.01 & 0.98 & \\
\hline Ricketts & 1998 & $\mathrm{TCl}$ & 37 & nd & nd & Caucasian & YES & 2.10 & 0.15 & \\
\hline Flory & 1999 & NEO & 225 & 50 & 45.7 & 84\% Caucasian & YES & 0.16 & 0.69 & \\
\hline Hamer & 1999 & $\mathrm{TCl}$ & 634 & 43 & 31.3 & 79\% Caucasian & NO & 3.85 & 0.04 & Excluded $^{b}$ \\
\hline Katsuragi & 1999 & $\mathrm{TCl}$ & 101 & 61 & 25.0 & Asian & YES & 0.02 & 0.88 & \\
\hline Kumakiri & 1999 & Both & 144 & 42 & 24.4 & Asian & YES & 1.28 & 0.26 & \\
\hline Benjamin & 2000 & $\mathrm{TCl}$ & 455 & 40 & nd & Caucasian & N/A & & & Excluded $^{d}$ \\
\hline Comings & 2000 & $\mathrm{TCl}$ & 81 & 100 & 32.9 & Caucasian & YES & 0.10 & 0.75 & \\
\hline Du & 2000 & NEO & 186 & 41 & 36.3 & Caucasian & YES & 0.77 & 0.38 & \\
\hline Greenberg & 2000 & NEO & 397 & 16 & 28.6 & Caucasian & $\mathrm{NO}$ & 4.75 & 0.03 & Excluded $^{b}$ \\
\hline Herbst & 2000 & $\mathrm{TCl}$ & 425 & 51 & 43.8 & 67\% Caucasian & YES & 0.79 & 0.38 & \\
\hline $\mathrm{Hu}$ & 2000 & NEO & 759 & 62 & 29.2 & 81\% Caucasian & YES & 1.57 & 0.21 & \\
\hline Osher & 2000 & Both & 148 & 34 & 30.7 & Caucasian & YES & 0.11 & 0.75 & \\
\hline Schmidt & 2000 & NEO & 72 & 48 & 27.0 & 54\% Caucasian & YES & 0.06 & 0.80 & Excluded $^{c}$ \\
\hline Samochowiec & 2001 & $\mathrm{TCl}$ & 126 & 30 & 23.8 & Caucasian & YES & 1.26 & 0.26 & \\
\hline Cohen & 2002 & $\mathrm{TCl}$ & 559 & 0 & nd & Caucasian & $\mathrm{NO}$ & 9.51 & 0.01 & Excluded $^{b}$ \\
\hline Tsai & 2002 & $\mathrm{TCl}$ & 192 & 49 & 29.3 & Asian & YES & 2.30 & 0.13 & \\
\hline Brummett & 2003 & NEO & 99 & 32 & 70.3 & 87\% Caucasian & YES & 0.70 & 0.40 & \\
\hline Umekage & 2003 & NEO & 244 & 8 & 37.7 & Asian & YES & 2.08 & 0.15 & \\
\hline Ham & 2004 & $\mathrm{TCl}$ & 146 & 32 & 31.9 & Asian & YES & 0.01 & 0.98 & \\
\hline Jacob & 2004 & Both & 281 & 25 & 22.4 & Caucasian & YES & 0.59 & 0.44 & \\
\hline Lang & 2004 & NEO & 228 & 50 & 38.6 & Caucasian & YES & 1.14 & 0.29 & \\
\hline Park & 2004 & $\mathrm{TCl}$ & 100 & 0 & 48.3 & Asian & YES & 2.41 & 0.12 & Excluded $^{d}$ \\
\hline Samochowiec & 2004 & Both & 100 & 47 & 41.0 & Caucasian & YES & 0.04 & 0.85 & \\
\hline Szekely & 2004 & $\mathrm{TCl}$ & 151 & 43 & 22.2 & Caucasian & YES & 0.59 & 0.44 & \\
\hline Thierry & 2004 & $\mathrm{TCl}$ & 76 & 0 & 32.8 & Caucasian & YES & 0.01 & 0.96 & Excluded $^{d}$ \\
\hline Sen & 2004 & NEO & 415 & 33 & 43.8 & Caucasian & $\mathrm{NO}$ & 3.76 & 0.05 & Excluded $^{b}$ \\
\hline
\end{tabular}


Table 2 Characteristics of association studies eligible for inclusion (Continued)

\begin{tabular}{|c|c|c|c|c|c|c|c|c|c|c|}
\hline Bachner-Melman & 2005 & $\mathrm{TCl}$ & 872 & nd & 21.4 & $\mathrm{~N} / \mathrm{A}$ & $\mathrm{N} / \mathrm{A}$ & & & Excluded $^{c, d}$ \\
\hline Hariri & 2005 & $\mathrm{TCl}$ & 92 & 49 & 30.5 & Caucasian & $\mathrm{N} / \mathrm{A}$ & & & Excluded $^{d}$ \\
\hline Kim & 2005 & $\mathrm{TCl}$ & 211 & 51 & 26.5 & Asian & YES & 0.06 & 0.81 & Excluded $^{d}$ \\
\hline Kremer & 2005 & $\mathrm{TCl}$ & 730 & nd & nd & N/A & $\mathrm{N} / \mathrm{A}$ & & & Excluded ${ }^{c, d}$ \\
\hline Dragan & 2006 & NEO & 196 & 0 & 21.7 & Caucasian & YES & 2.07 & 0.15 & \\
\hline Lazagorta & 2006 & $\mathrm{TCl}$ & 57 & nd & 45 & Other & YES & 3.70 & 0.05 & Excluded $^{b, c}$ \\
\hline Monteleone & 2006 & $\mathrm{TCl}$ & 94 & 0 & nd & Caucasian & YES & 2.37 & 0.12 & \\
\hline Serretti & 2006 & $\mathrm{TCl}$ & 132 & nd & nd & Caucasian & YES & 0.02 & 0.90 & \\
\hline Vorfelde & 2006 & Both & 195 & 50 & nd & Caucasian & YES & 0.48 & 0.49 & \\
\hline Hunnerkopf & 2007 & NEO & 272 & 25 & 21.9 & Caucasian & $\mathrm{N} / \mathrm{A}$ & & & Excluded $^{d}$ \\
\hline Joo & 2007 & $\mathrm{TCl}$ & 158 & 44 & 23.8 & Asian & YES & 0.13 & 0.72 & \\
\hline Nilsson & 2007 & $\mathrm{TCl}$ & 196 & 60 & 17 & Caucasian & YES & 1.07 & 0.30 & \\
\hline Schmitz & 2007 & Both & 410 & 36 & 24 & Caucasian & YES & 0.07 & 0.78 & \\
\hline Stein & 2008 & NEO & 247 & 31 & 18.8 & $61 \%$ Caucasian & $\mathrm{NO}$ & 3.88 & 0.05 & Excluded $^{b}$ \\
\hline Lee & 2008 & $\mathrm{TCl}$ & 75 & 100 & 16.1 & Asian & YES & 2.97 & 0.08 & Excluded $^{d}$ \\
\hline Kazantseva & 2008 & $\mathrm{TCl}$ & 301 & 20 & 19.8 & Caucasian & YES & 1.24 & 0.26 & \\
\hline Suzuki & 2008 & $\mathrm{TCl}$ & 575 & 51 & 28.7 & Asian & YES & 0.14 & 0.71 & \\
\hline Munafò & 2009 & $\mathrm{TCl}$ & 3872 & 44 & 42 & Caucasian & YES & 0.26 & 0.61 & \\
\hline Gonda & 2009 & $\mathrm{TCl}$ & 169 & 0 & nd & Caucasian & YES & 0.20 & 0.65 & \\
\hline Terracciano $^{e}$ & 2009 & NEO & 3972 & 43 & 42.5 & Caucasian & YES & 1.33 & 0.25 & \\
\hline Terracciano $^{\mathrm{f}}$ & 2009 & NEO & 1182 & 52 & 57.3 & 71\% Caucasian & YES & 0.87 & 0.35 & \\
\hline Saiz & 2010 & $\mathrm{TCl}$ & 404 & 50 & 40.5 & Caucasian & YES & 0.76 & 0.38 & \\
\hline Present Study & & $\mathrm{TCl}$ & 229 & 45 & 49.2 & Caucasian & YES & 0.33 & 0.56 & \\
\hline
\end{tabular}

$\mathrm{HW}=$ Hardy-Weinberg; HW $\chi 2=$ Hardy-Weinberg chi square; HW $\mathrm{p}=$ Hardy-Weinberg $p$ value; nd = not determined; $\mathrm{N} / \mathrm{A}=$ not applicable.

${ }^{a}$ The term NEO referred to all versions (i.e. NEO-PI, NEO-PI-R, NEO-FFI); the term TCI referred to all versions (TPQ).

${ }^{b}$ Excluded because genotype frequencies showed deviation from Hardy-Weinberg equilibrium.

c Excluded due to the ethnic heterogeneity or lack of data about ethnic origin.

${ }^{d}$ Excluded because of unavailable data.

e Data referred to SardiNIA sample.

${ }^{f}$ Data referred to BLSA (Baltimore Longitudinal Study of Aging) sample.

and no evidence of between-study heterogeneity was apparent. A significant association with $\mathrm{N}(\mathrm{p}<0.01)$, indicating a higher anxiety trait score, and evidence of highly significant between-study heterogeneity $\left(\mathrm{p}<0.0001, \mathrm{I}^{2}=\right.$ $74 \%$ ) were found in the $S$ allele carriers group. When the analysis was run again using the random effects method, the significant effect just described was no longer significant. No evidence for an association between the 5HTTLPR genotype and N ( $=0.09)$ as well as no overall effect $(\mathrm{p}=0.11)$ was shown.

When we tested the $\mathrm{L}$ allele carriers versus the SS genotype in the same ethnic population (Figure 2), no association was found between 5-HTTLPR and HA or $\mathrm{N}$, and there was no evidence of between-study heterogeneity. Instead, a significant overall effect was obtained $(\mathrm{p}=0.03)$, and the two subgroups did not show significant differences $\left(\chi^{2}[1]=0.01, \mathrm{p}=0.95, \mathrm{I}^{2}=0 \%\right)$.

In the Asian population, no association was observed between the LL genotype and carriers of the $\mathrm{S}$ allele, using either TCI $(\mathrm{d}=-0.01,95 \% \mathrm{CI}=-0.24,0.22, \mathrm{Z}=$ $0.10, \mathrm{p}=0.92)$ or NEO $(\mathrm{d}=-0.15,95 \% \mathrm{CI}=-0.54,0.24$, $\mathrm{Z}=0.75, \mathrm{p}=0.46)$. After clustering of the $\mathrm{L}$ allele carriers versus the SS genotype, there was no significant evidence of an association between 5-HTTLPR and either HA or $\mathrm{N}(\mathrm{d}=-0.06,95 \% \mathrm{CI}=-0.16,0.04, \mathrm{Z}=$ $1.13, \mathrm{p}=0.26$; and $\mathrm{d}=-0.12,95 \% \mathrm{CI}=-0.29,0.05, \mathrm{Z}=$ $1.38, \mathrm{p}=0.17$; respectively). We did not find betweenstudy heterogeneity in any groups.

Because of the bias inherent in a mix of healthy subjects with depressed or anxious people, we carried out a meta-analysis including only the studies with structured psychiatric interview screening $[42,43,59,66,73,75,88]$. No significant result was found when we considered an L dominant model (TCI: $\mathrm{d}=0.00,95 \% \mathrm{CI}-0.12,0.12, \mathrm{Z}$ $=0.01, \mathrm{p}=1.00$; NEO: $\mathrm{d}=-0.02,95 \% \mathrm{CI}-0.22,0.18, \mathrm{Z}$ $=0.19, \mathrm{p}=0.85$; Overall effect $\mathrm{p}=0.92)$ or a recessive model (TCI: $\mathrm{d}=-0.10,95 \% \mathrm{CI}=-0.25,0.04, \mathrm{Z}=1.40, \mathrm{p}$ $=0.16$; NEO: $\mathrm{d}=-0.12,95 \% \mathrm{CI}=-0.39,0.14, \mathrm{Z}=0.93$, $\mathrm{p}=0.35$; Overall effect $\mathrm{p}=0.09$ ).

\section{Discussion}

The present study demonstrates the relevance of employing more stringent inclusion/exclusion criteria in association studies on healthy subjects. Our results show 


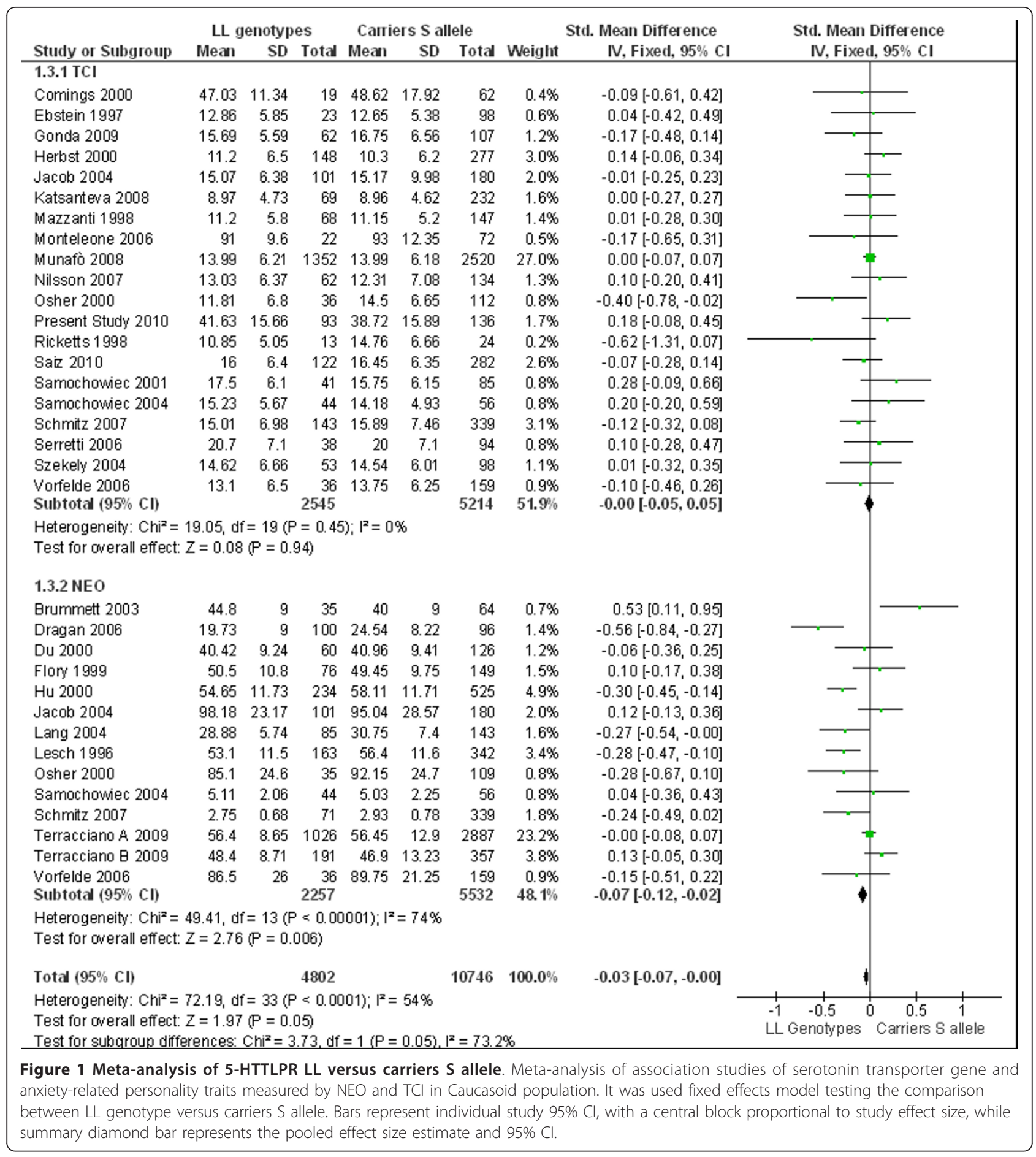

the influence of mistakes in the selection of subjects, underscoring the importance of the use of a structured psychiatric interview when people are enrolled as control subjects for this type of study. When we performed analyses on the whole sample of 287 volunteers, effects on the susceptibility to HA were found for both the SS genotype and the S'S' haplotypes. However, because the screening performed by M.I.N.I. revealed the presence of depression or anxiety disorders in 55 volunteers (the "disordered" group), we verified the possible influence of the variable "groups" ("healthy" and "disordered") on the genotypes. The results evidenced a significant interaction between genotypes and groups (5-HTTLPR; p = 0.03 and 5-HTTLPR/rs25531 L'L' + L'S' vs. S'S'; p = 


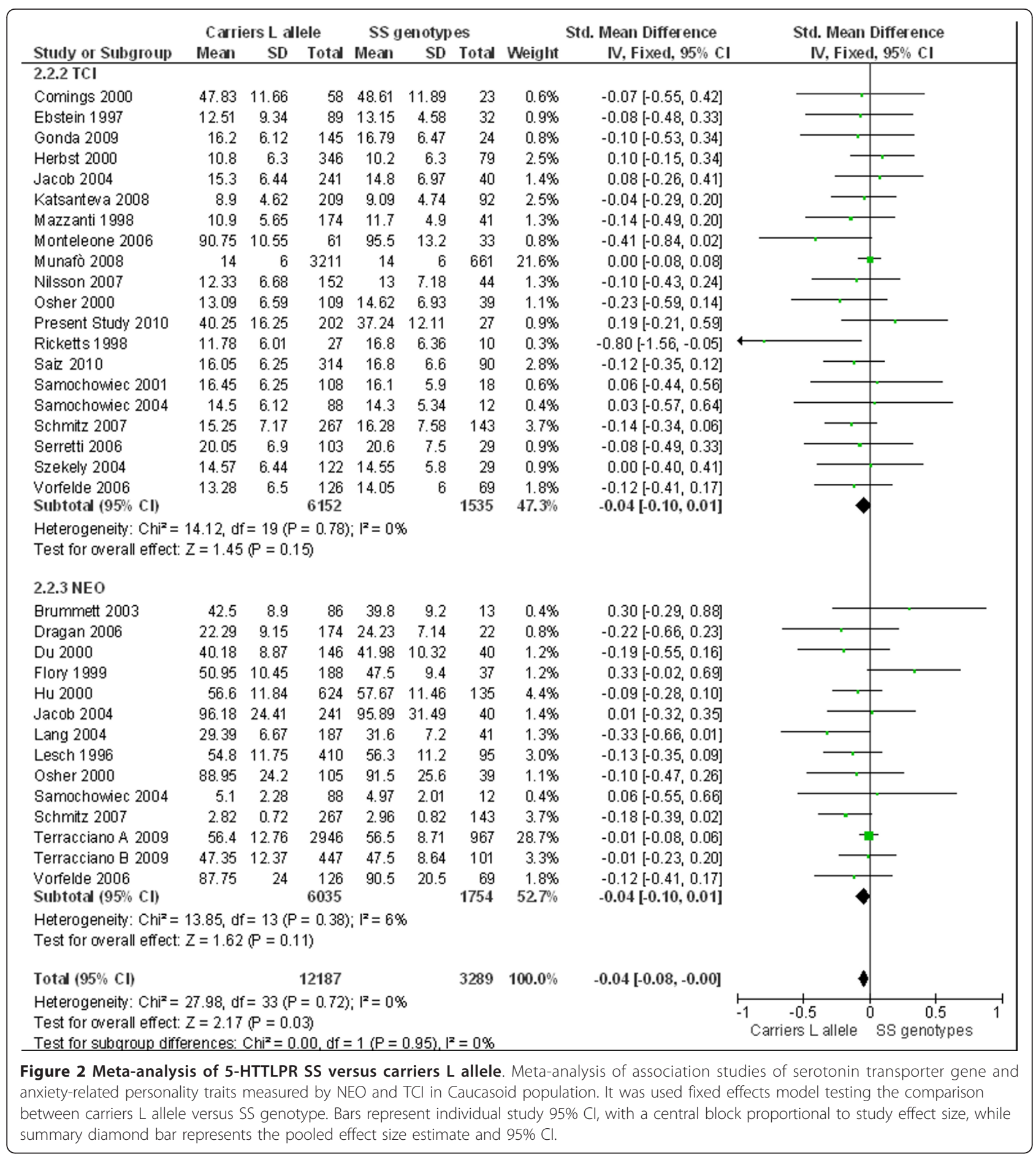

0.02); thus, we conducted the analyses separately for these groups. The data confirmed that in the "healthy" group, the effects of the SS genotype and the S'S' haplotypes were lost, but they remained in the "disordered" group. In addition, we conducted a meta-analysis involving approximately 18,000 controls of Caucasoid and Asian descent and considering anxiety traits measured by TPQ/TCI or NEO. Similarly, an association was observed between $\mathrm{S}$ allele in homozygosity and higher scores for anxiety-related traits, but when we analyzed only the studies that used structured psychiatric screening, no association was found.

Moreover, another important finding from both STUDY I and STUDY II is the absence of a role of the 
serotonin transporter gene in anxiety personality traits in healthy subjects.

To date, five meta-analyses have been conducted on the involvement of the functional 5-HTTLPR polymorphism with anxiety personality traits [20-24]. Schinka's and Sen's meta-analyses [23,24] found a strong association of 5-HTTLPR with $\mathrm{N}$ and no link to HA, whereas Munafò [20-22] reported contrasting data; in particular no strong effect was detected $[20,22]$ and, when present, it was small [21]. As discussed in the 2005 study by Munafò [21], the association found in Schinka and Sen's meta-analyses [23,24] may have been biased by the inclusion of studies that recruited participants from psychiatric populations. However, there is another bias that the Munafò meta-analyses [20-22] did not take in consideration: the presence of studies in which structured psychiatric screening was not performed, producing a lack of information about the patients' lifetime history of psychiatric disorders. On this basis, we tried to verify whether the absence of a psychiatric screening interview might represent an important confounding variable in studies regarding the biological basis of personality traits in healthy populations. Indeed, STUDY I indicated an association between the SS genotype and S'S' haplotypes in 5HTTLPR/rs25531 and anxiety traits in the whole sample of volunteers, but these effects were probably found due to the presence of subjects with depression and anxiety disorders. In fact, as reported in Table 1, these subjects have higher scores for HA and a higher frequency of homozygous SS or S'S'. More importantly, the results of STUDY II lead to the same direction.

It is well known that anxiety traits are strongly linked to depression and anxiety disorders [25-28,33-36,89] and indeed, the premorbid depressive personality represents an emotional vulnerability that increases the likelihood of developing these disorders during stressful life events. Furthermore, the literature supports the hypothesis that 5 -HTTLPR S allele could be a risk factor for major depression/anxiety spectrum disorders [29]. Taking together the two issues, our findings seem to be contradictory. However, recently it has been proposed the hypothesis about a role of the SLC6A4 gene not directly in the MDD susceptibility but rather in the some features of the pathology such as the response/resistance to antidepressant treatment [5-8], or the interaction with the stressful life events, given the robust correlation between these events and risk of developing depressive symptoms [9-11,90].

In our recent paper [8], we have supported the evidence about the modulation of 5-HTTLPR by rs 25531 showing that $\mathrm{L}_{\mathrm{G}}$ haplotype has lower transcriptional efficacy as well as the S allele. Therefore, in STUDY I we conducted association analyses for 5 -HTTLPR/rs 25531 to investigate the influence of rs25531. The results showed the association with HA in the "disordered group". In light of these data, we speculate that the genotyping of both the functional polymorphisms (5-HTTLPR and rs25531) and the haplotypes analysis should be taken into account in relation to anxietyrelated personality traits.

Finally, in STUDY II, because the S allele is much more prevalent in Asians than in Caucasians [41,49,58], suggesting that ethnic differences may be a confounding factor in association studies of the 5-HTTLPR genotype, we conducted separate analyses for both populations to avoid biased conclusions. No significant association was found between 5-HTTLPR and either N or HA.

\section{Conclusions}

This study supports the following conclusions: 1. A lack of structured psychiatric screening of subjects may produce an important bias in genetic association studies on personality traits using controls. The symptomatology of depressive and anxiety disorders might interfere with anxiety-related traits in possible associations with the serotonin transporter and the higher frequency of the $\mathrm{S}$ allele observed in depressed and anxiety disorder patients; 2. The SLC6A4 gene is not involved in anxietyrelated traits measured by TCI and NEO in psychiatrically healthy subjects.

\section{Acknowledgements and Funding}

This research was supported by grants from the Italian Ministry of Health and the CARIPLO Foundation. We thank Luisa Boventi and Francesco Roversi for laboratory support. Furthermore, the authors would like to express sincere gratitude to all the people who participated in the study.

\section{Author details}

${ }^{1}$ Genetic Unit, I.R.C.C.S. "San Giovanni di Dio" - Fatebenefratelli, Brescia, Italy. ${ }^{2}$ Department of Philosophy, Pedagogy, Psychology, University of Verona, Verona, Italy. ${ }^{3}$ Department of Biomedical Sciences and Biotechnologies, Biology and Genetic Division, University School of Medicine, Brescia, Italy.

\section{Authors' contributions}

AM conceived of the study, participated in its design and the coordination and acquisition of data, performed the statistical analyses, and co-wrote the manuscript; CB participated in the design of the study, performed the statistical analyses and carried out all genetic analyses; CS participated in the design and coordination of the study and co-wrote the manuscript; RS performed the statistical analyses and helped draft the manuscript; MG conceived of the study, participated in its design and coordination, and helped draft the manuscript and critically reviewed it for intellectual content. All the authors read and approved the final manuscript.

\section{Conflict of interests}

The authors declare that they have no competing interests.

Received: 4 August 2010 Accepted: 31 March 2011

Published: 31 March 2011

\section{References}

1. Bouchard TJ Jr, Loehlin JC: Genes, evolution, and personality. Behav Genet 2001, 31(3):243-273.

2. Heils A, Teufel A, Petri S, Stober G, Riederer P, Bengel D, Lesch KP: Allelic variation of human serotonin transporter gene expression. J Neurochem 1996, 66(6):2621-2624. 
3. Lesch KP, Bengel D, Heils A, Sabol SZ, Greenberg BD, Petri S, Benjamin J, Muller CR, Hamer DH, Murphy DL: Association of anxiety-related traits with a polymorphism in the serotonin transporter gene regulatory region. Science 1996, 274(5292):1527-1531.

4. Hu XZ, Lipsky RH, Zhu G, Akhtar LA, Taubman J, Greenberg BD, Xu K Arnold PD, Richter MA, Kennedy JL, et al: Serotonin transporter promoter gain-of-function genotypes are linked to obsessive-compulsive disorder. Am J Hum Genet 2006, 78(5):815-826.

5. Zandi PP, Judy JT: The promise and reality of pharmacogenetics in psychiatry. Clin Lab Med 30(4):931-974.

6. Serretti A, Kato M, De Ronchi D, Kinoshita T: Meta-analysis of serotonin transporter gene promoter polymorphism (5-HTTLPR) association with selective serotonin reuptake inhibitor efficacy in depressed patients. $\mathrm{Mol}$ Psychiatry 2007, 12(3):247-257.

7. Horstmann S, Binder EB: Pharmacogenomics of antidepressant drugs. Pharmacol Ther 2009, 124(1):57-73.

8. Bonvicini C, Minelli A, Scassellati C, Bortolomasi M, Segala M, Sartori R, Giacopuzzi M, Gennarelli M: Serotonin transporter gene polymorphisms and treatment-resistant depression. Prog Neuropsychopharmacol Biol Psychiatry 34(6):934-939.

9. Uher R, McGuffin P: The moderation by the serotonin transporter gene of environmental adversity in the etiology of depression: 2009 update. $\mathrm{Mol}$ Psychiatry 15(1):18-22.

10. Wankerl M, Wust S, Otte C: Current developments and controversies: does the serotonin transporter gene-linked polymorphic region (5HTTLPR) modulate the association between stress and depression? Cur Opin Psychiatry 23(6):582-587.

11. Caspi A, Hariri AR, Holmes A, Uher R, Moffitt TE: Genetic sensitivity to the environment: the case of the serotonin transporter gene and its implications for studying complex diseases and traits. Am J Psychiatry 167(5):509-527.

12. Lipsky $\mathrm{RH}, \mathrm{Hu} X Z$, Goldman D: Additional functional variation at the SLC6A4 gene. Am J Med Genet B Neuropsychiatr Genet 2009, 150B(1):153.

13. Wendland JR, Moya PR, Kruse MR, Ren-Patterson RF, Jensen $C L$, Timpano KR, Murphy DL: A novel, putative gain-of-function haplotype at SLC6A4 associates with obsessive-compulsive disorder. Hum Mol Genet 2008, 17(5):717-723.

14. Martin J, Cleak J, Willis-Owen SA, Flint J, Shifman S: Mapping regulatory variants for the serotonin transporter gene based on allelic expression imbalance. Mol Psychiatry 2007, 12(5):421-422.

15. Costa PT Jr, McCrae RR: Revised NEO personality inventory (NEO-PI-R) and NEO five-factor inventory (NEO-FFI) professional manual. Odessa, FL: Psychological Assessment Resources; 1992

16. Cloninger CR, Svrakic DM, Przybeck TR: A psychobiological model of temperament and character. Arch Gen Psychiatry 1993, 50(12):975-990.

17. Zuckerman M, Cloninger CR: Relationships between Cloninger's, Zuckerman's, and Eysenck's dimension of personality. Pers Individ Differ 1996, 21(2):283-285.

18. Sher KJ, Bartholow BD, Wood MD: Personality and substance use disorders: a prospective study. J Consult Clin Psychol 2000, 68(5):818-829.

19. De Fruyt F, De Clercq BJ, van de Wiele L, Van Heeringen K: The validity of Cloninger's psychobiological model versus the five-factor model to predict DSM-IV personality disorders in a heterogeneous psychiatric sample: domain facet and residualized facet descriptions. J Pers 2006 74(2):479-510.

20. Munafo MR, Clark TG, Moore LR, Payne E, Walton R, Flint J: Genetic polymorphisms and personality in healthy adults: a systematic review and meta-analysis. Mol Psychiatry 2003, 8(5):471-484.

21. Munafo MR, Clark T, Flint J: Does measurement instrument moderate the association between the serotonin transporter gene and anxiety-related personality traits? A meta-analysis. Mol Psychiatry 2005, 10(4):415-419.

22. Munafo MR, Freimer NB, Ng W, Ophoff R, Veijola J, Miettunen J, Jarvelin MR, Taanila A, Flint J: 5-HTTLPR genotype and anxiety-related personality traits: a meta-analysis and new data. Am J Med Genet B Neuropsychiatr Genet 2009, 150B(2):271-281.

23. Schinka JA, Busch RM, Robichaux-Keene N: A meta-analysis of the association between the serotonin transporter gene polymorphism (5HTTLPR) and trait anxiety. Mol Psychiatry 2004, 9(2):197-202.

24. Sen S, Burmeister M, Ghosh D: Meta-analysis of the association between a serotonin transporter promoter polymorphism (5-HTTLPR) and anxiety- related personality traits. Am J Med Genet B Neuropsychiatr Genet 2004, 127B(1):85-89.

25. Smith DJ, Duffy L, Stewart ME, Muir WJ, Blackwood DH: High harm avoidance and low self-directedness in euthymic young adults with recurrent, early-onset depression. J Affect Disord 2005, 87(1):83-89.

26. Matsudaira T, Kitamura T: Personality traits as risk factors of depression and anxiety among Japanese students. J Clin Psychol 2006, 62(1):97-109.

27. Jylha $\mathrm{P}$, Isometsa E: Temperament, character and symptoms of anxiety and depression in the general population. Eur Psychiatry 2006, 21(6):389-395

28. de Winter RF, Wolterbeek R, Spinhoven P, Zitman FG, Goekoop JG: Character and temperament in major depressive disorder and a highly anxious-retarded subtype derived from melancholia. Compr Psychiatry 2007, 48(5):426-435

29. Holsboer F: How can we realize the promise of personalized antidepressant medicines? Nat Rev Neurosci 2008, 9(8):638-646.

30. Sheehan DV, Lecrubier $Y$, Sheehan $K H$, Amorim P, Janavs J, Weiller $E$, Hergueta T, Baker R, Dunbar GC: The Mini-International Neuropsychiatric Interview (M.I.N.I.): the development and validation of a structured diagnostic psychiatric interview for DSM-IV and ICD-10. J Clin Psychiatry 1998, 59(Suppl 20):22-33, quiz 34-57.

31. Martinotti G, Mandelli L, Di Nicola M, Serretti A, Fossati A, Borroni S, Cloninger CR, Janiri L: Psychometric characteristic of the Italian version of the Temperament and Character Inventory-revised, personality, psychopathology, and attachment styles. Compr Psychiatry 2008, 49(5):514-522.

32. Folstein MF, Folstein SE, McHugh PR: "Mini-mental state". A practical method for grading the cognitive state of patients for the clinician. $J$ Psychiatr Res 1975, 12(3):189-198.

33. Hirano S, Sato T, Narita T, Kusunoki K, Ozaki N, Kimura S, Takahashi T, Sakado K, Uehara T: Evaluating the state dependency of the Temperament and Character Inventory dimensions in patients with major depression: a methodological contribution. J Affect Disord 2002, 69(1-3):31-38

34. Marijnissen G, Tuinier S, Sijben AE, Verhoeven WM: The temperament and character inventory in major depression. J Affect Disord 2002, 70(2):219-223.

35. Farmer A, Mahmood A, Redman K, Harris T, Sadler S, McGuffin P: A sib-pair study of the Temperament and Character Inventory scales in major depression. Arch Gen Psychiatry 2003, 60(5):490-496.

36. Abrams KY, Yune SK, Kim SJ, Jeon HJ, Han SJ, Hwang J, Sung YH, Lee KJ, Lyoo IK: Trait and state aspects of harm avoidance and its implication for treatment in major depressive disorder, dysthymic disorder, and depressive personality disorder. Psychiatry Clin Neurosci 2004, 58(3):240-248.

37. Strobel A, Brocke B, Ebstein RP: Interektionseffekte monoaminrelevanter genetischer polymorphismen mit traits des TPQ [Interaction effects of monoamine-relevant genetic polymorphisms with traits of the TPQ]. Z Different Diagnost Psychol 2000, 21:194-199.

38. Higgins JP, Thompson SG, Deeks JJ, Altman DG: Measuring inconsistency in meta-analyses. Bmj 2003, 327(7414):557-560.

39. DerSimonian R, Laird N: Meta-analysis in clinical trials. Control Clin Trials 1986, 7(3):177-188

40. Ebstein RP, Gritsenko I, Nemanov L, Frisch A, Osher Y, Belmaker RH: No association between the serotonin transporter gene regulatory region polymorphism and the Tridimensional Personality Questionnaire (TPQ) temperament of harm avoidance. Mol Psychiatry 1997, 2(3):224-226.

41. Nakamura T, Muramatsu T, Ono $Y$, Matsushita S, Higuchi S, Mizushima H, Yoshimura K, Kanba S, Asai M: Serotonin transporter gene regulatory region polymorphism and anxiety-related traits in the Japanese. Am J Med Genet 1997, 74(5):544-545.

42. Mazzanti CM, Lappalainen J, Long JC, Bengel D, Naukkarinen H, Eggert M, Virkkunen M, Linnoila M, Goldman D: Role of the serotonin transporter promoter polymorphism in anxiety-related traits. Arch Gen Psychiatry 1998, 55(10):936-940

43. Monteleone P, Santonastaso P, Mauri M, Bellodi L, Erzegovesi S, Fuschino A, Favaro A, Rotondo A, Castaldo E, Maj M: Investigation of the serotonin transporter regulatory region polymorphism in bulimia nervosa: relationships to harm avoidance, nutritional parameters, and psychiatric comorbidity. Psychosom Med 2006, 68(1):99-103. 
44. Ricketts MH, Hamer RM, Sage Jl, Manowitz P, Feng F, Menza MA: Association of a serotonin transporter gene promoter polymorphism with harm avoidance behaviour in an elderly population. Psychiatr Genet 1998, 8(2):41-44

45. Flory JD, Manuck SB, Ferrell RE, Dent KM, Peters DG, Muldoon MF: Neuroticism is not associated with the serotonin transporter (5-HTTLPR) polymorphism. Mol Psychiatry 1999, 4(1):93-96.

46. Hamer DH, Greenberg BD, Sabol SZ, Murphy DL: Role of the serotonin transporter gene in temperament and character. J Pers Disord 1999, 13(4):312-327.

47. Katsuragi S, Kunugi H, Sano A, Tsutsumi T, Isogawa K, Nanko S, Akiyoshi J: Association between serotonin transporter gene polymorphism and anxiety-related traits. Biol Psychiatry 1999, 45(3):368-370.

48. Kazantseva AV, Gaysina DA, Faskhutdinova GG, Noskova T, Malykh SB, Khusnutdinova EK: Polymorphisms of the serotonin transporter gene (5HTTLPR, A/G SNP in 5-HTTLPR, and STin2 VNTR) and their relation to personality traits in healthy individuals from Russia. Psychiatr Genet 2008, 18(4):167-176.

49. Kumakiri C, Kodama K, Shimizu E, Yamanouchi N, Okada S, Noda S, Okamoto H, Sato T, Shirasawa H: Study of the association between the serotonin transporter gene regulatory region polymorphism and personality traits in a Japanese population. Neurosci Lett 1999, 263(23):205-207.

50. Benjamin J, Osher Y, Kotler M, Gritsenko I, Nemanov L, Belmaker RH, Ebstein RP: Association between tridimensional personality questionnaire (TPQ) traits and three functional polymorphisms: dopamine receptor D4 (DRD4), serotonin transporter promoter region (5-HTTLPR) and catechol O-methyltransferase (COMT). Mol Psychiatry 2000, 5(1):96-100.

51. Du L, Bakish D, Hrdina PD: Gender differences in association between serotonin transporter gene polymorphism and personality traits. Psychiatr Genet 2000, 10(4):159-164.

52. Greenberg BD, Li Q, Lucas FR, Hu S, Sirota LA, Benjamin J, Lesch KP Hamer D, Murphy DL: Association between the serotonin transporter promoter polymorphism and personality traits in a primarily female population sample. Am J Med Genet 2000, 96(2):202-216.

53. Herbst JH, Zonderman AB, McCrae RR, Costa PT Jr: Do the dimensions of the temperament and character inventory map a simple genetic architecture? Evidence from molecular genetics and factor analysis. Am J Psychiatry 2000, 157(8):1285-1290.

54. Hu S, Brody CL, Fisher C, Gunzerath L, Nelson ML, Sabol SZ, Sirota LA Marcus SE, Greenberg BD, Murphy DL, et al: Interaction between the serotonin transporter gene and neuroticism in cigarette smoking behavior. Mol Psychiatry 2000, 5(2):181-188.

55. Osher $Y$, Hamer D, Benjamin J: Association and linkage of anxiety-related traits with a functional polymorphism of the serotonin transporter gene regulatory region in Israeli sibling pairs. Mol Psychiatry 2000, 5(2):216-219.

56. Schmidt NB, Storey J, Greenberg BD, Santiago HT, Li Q, Murphy DL: Evaluating gene $\times$ psychological risk factor effects in the pathogenesis of anxiety: a new model approach. J Abnorm Psychol 2000, 109(2):308-320.

57. Samochowiec J, Rybakowski F, Czerski P, Zakrzewska M, Stepien G, PelkaWysiecka J, Horodnicki J, Rybakowski JK, Hauser J: Polymorphisms in the dopamine, serotonin, and norepinephrine transporter genes and their relationship to temperamental dimensions measured by the Temperament and Character Inventory in healthy volunteers. Neuropsychobiology 2001, 43(4):248-253.

58. Tsai SJ, Hong CJ, Cheng CY: Serotonin transporter genetic polymorphisms and harm avoidance in the Chinese. Psychiatr Genet 2002, 12(3):165-168.

59. Samochowiec J, Syrek S, Michal P, Ryzewska-Wodecka A, Samochowiec A, Horodnicki J, Zakrzewska M, Kucharska-Mazur J: Polymorphisms in the serotonin transporter and monoamine oxidase A genes and their relationship to personality traits measured by the Temperament and Character Inventory and NEO Five-Factor Inventory in healthy volunteers. Neuropsychobiology 2004, 50(2):174-181.

60. Sen S, Villafuerte S, Nesse R, Stoltenberg SF, Hopcian J, Gleiberman L, Weder A, Burmeister M: Serotonin transporter and GABAA alpha 6 receptor variants are associated with neuroticism. Biol Psychiatry 2004 55(3):244-249

61. Szekely A, Ronai Z, Nemoda Z, Kolmann G, Gervai J, Sasvari-Szekely M: Human personality dimensions of persistence and harm avoidance associated with DRD4 and 5-HTTLPR polymorphisms. Am J Med Genet B Neuropsychiatr Genet 2004, 126B(1):106-110.
62. Thierry N, Willeit M, Praschak-Rieder N, Zill P, Hornik K, Neumeister A, Lenzinger E, Stastny J, Hilger E, Konstantinidis A, et al: Serotonin transporter promoter gene polymorphic region (5-HTTLPR) and personality in female patients with seasonal affective disorder and in healthy controls. Eur Neuropsychopharmacol 2004, 14(1):53-58.

63. Park JW, Kim JS, Lee HK, Kim Yl, Lee KS: Serotonin transporter polymorphism and harm avoidance personality in chronic tension-type headache. Headache 2004, 44(10):1005-1009.

64. Umekage T, Tochigi M, Marui T, Kato C, Hibino H, Otani T, Kohda K, Kato N, Sasaki T: Serotonin transporter-linked promoter region polymorphism and personality traits in a Japanese population. Neurosci Lett 2003, 337(1):13-16.

65. Lanzagorta N, Alexanderson-Rosas E, Ricalde A, Gomez Caudillo L, Sosa A, Camarena B, Aguilar A, Fresan A, Apiquian R, Nicolini H: [Effect to the serotonin transporter gene (5-HTT) on personality dimensions in individuals without psychopathology]. Actas Esp Psiquiatr 2006, 34(5):303-308.

66. Lang UE, Bajbouj M, Wernicke C, Rommelspacher H, Danker-Hopfe H, Gallinat J: No association of a functional polymorphism in the serotonin transporter gene promoter and anxiety-related personality traits. Neuropsychobiology 2004, 49(4):182-184.

67. Kim SJ, Kim YS, Choi NK, Hong HJ, Lee HS, Kim CH: Serotonin transporter gene polymorphism and personality traits in a Korean population. Neuropsychobiology 2005, 51(4):243-247.

68. Kremer I, Bachner-Melman R, Reshef A, Broude L, Nemanov L, Gritsenko I, Heresco-Levy U, Elizur Y, Ebstein RP: Association of the serotonin transporter gene with smoking behavior. Am J Psychiatry 2005, 162(5):924-930.

69. Jacob CP, Strobel A, Hohenberger K, Ringel T, Gutknecht L, Reif A, Brocke B, Lesch KP: Association between allelic variation of serotonin transporter function and neuroticism in anxious cluster C personality disorders. Am J Psychiatry 2004, 161(3):569-572.

70. Ham BJ, Kim YH, Choi MJ, Cha JH, Choi YK, Lee MS: Serotonergic genes and personality traits in the Korean population. Neurosci Lett 2004, 354(1):2-5.

71. Hariri AR, Drabant EM, Munoz KE, Kolachana BS, Mattay VS, Egan MF, Weinberger DR: A susceptibility gene for affective disorders and the response of the human amygdala. Arch Gen Psychiatry 2005, 62(2):146-152.

72. Dragan $\mathrm{WL}$, Oniszczenko $\mathrm{W}$ : Association of a functional polymorphism in the serotonin transporter gene with personality traits in females in a Polish population. Neuropsychobiology 2006, 54(1):45-50.

73. Brummett BH, Siegler IC, McQuoid DR, Svenson IK, Marchuk DA Steffens DC: Associations among the NEO Personality Inventory, Revised and the serotonin transporter gene-linked polymorphic region in elders: effects of depression and gender. Psychiatr Genet 2003, 13(1):13-18.

74. Cohen H, Buskila D, Neumann L, Ebstein RP: Confirmation of an association between fibromyalgia and serotonin transporter promoter region (5-HTTLPR) polymorphism, and relationship to anxiety-related personality traits. Arthritis Rheum 2002, 46(3):845-847.

75. Gonda X, Fountoulakis KN, Juhasz G, Rihmer Z, Lazary J, Laszik A, Akiskal HS Bagdy G: Association of the $s$ allele of the 5-HTTLPR with neuroticismrelated traits and temperaments in a psychiatrically healthy population. Eur Arch Psychiatry Clin Neurosci 2009, 259(2):106-113.

76. Lee YS, Han DH, Yang KC, Daniels MA, Na C, Kee BS, Renshaw PF: Depression like characteristics of 5 HTTLPR polymorphism and temperament in excessive internet users. J Affect Disord 2008, 109(12):165-169.

77. Joo YH, Oh HB, Kim B, Jung SH, Chung JK, Hong JP, Kim CY: No association between 5-HTTLPR and harm avoidance in Korean college students. J Korean Med Sci 2007, 22(1):138-141.

78. Hunnerkopf R, Strobel A, Gutknecht L, Brocke B, Lesch KP: Interaction between BDNF Val66Met and dopamine transporter gene variation influences anxiety-related traits. Neuropsychopharmacology 2007 32(12):2552-2560.

79. Nilsson KW, Damberg M, Ohrvik J, Leppert J, Lindstrom L, Anckarsater H, Oreland L: Genes encoding for AP-2beta and the Serotonin Transporter are associated with the Personality Character Spiritual Acceptance. Neurosci Lett 2007, 411(3):233-237.

80. Serretti A, Mandelli L, Lorenzi C, Landoni S, Calati R, Insacco C, Cloninger CR: Temperament and character in mood disorders: influence of DRD4, SERTPR, TPH and MAO-A polymorphisms. Neuropsychobiology 2006, 53(1):9-16 
81. Stein MB, Schork NJ, Gelernter J: Gene-by-environment (serotonin transporter and childhood maltreatment) interaction for anxiety sensitivity, an intermediate phenotype for anxiety disorders. Neuropsychopharmacology 2008, 33(2):312-319.

82. Suzuki A, Matsumoto Y, Oshino S, Kamata M, Goto K, Otani K: Combination of the serotonin transporter and norepinephrine transporter gene promoter polymorphisms might influence harm avoidance and novelty seeking in healthy females. Neurosci Lett 2008, 439(1):52-55.

83. Terracciano A, Balaci L, Thayer J, Scally M, Kokinos S, Ferrucci L, Tanaka T, Zonderman AB, Sanna $\mathrm{S}$, Olla N, et al: Variants of the serotonin transporter gene and NEO-PI-R Neuroticism: No association in the BLSA and SardiNIA samples. Am J Med Genet B Neuropsychiatr Genet 2009.

84. Vormfelde SV, Hoell I, Tzvetkov M, Jamrozinski K, Sehrt D, Brockmoller J, Leibing E: Anxiety- and novelty seeking-related personality traits and serotonin transporter gene polymorphisms. J Psychiatr Res 2006, 40(6):568-576.

85. Schmitz A, Hennig J, Kuepper Y, Reuter M: The association between neuroticism and the serotonin tranporter polymorphism depends on structural differences between personality measures. Pers Individ Differ 2007, 42(4):789-799.

86. Bachner-Melman R, Dina C, Zohar AH, Constantini N, Lerer E, Hoch S, Sella S, Nemanov L, Gritsenko I, Lichtenberg P, et al: AVPR1a and SLC6A4 gene polymorphisms are associated with creative dance performance. PLoS Genet 2005, 1(3):e42.

87. Comings DE, Gade-Andavolu R, Gonzalez N, Wu S, Muhleman D, Blake H, Mann MB, Dietz G, Saucier G, MacMurray JP: A multivariate analysis of 59 candidate genes in personality traits: the temperament and character inventory. Clin Genet 2000, 58(5):375-385.

88. Saiz PA, Garcia-Portilla MP, Herrero R, Arango C, Corcoran P, Morales B, Bascaran MT, Alvarez V, Coto E, Paredes B, et al: Interactions between functional serotonergic polymorphisms and demographic factors influence personality traits in healthy Spanish Caucasians. Psychiatr Genet

89. Minelli A, Pedrini L, Magni LR, Rotondo A: Personality traits in an italian sample: relationship with anxiety and depression. Clin Pract Epidemiol Ment Health 2009, 5:26-30.

90. Goldman N, Glei DA, Lin YH, Weinstein M: The serotonin transporter polymorphism (5-HTTLPR): allelic variation and links with depressive symptoms. Depress Anxiety 27(3):260-269.

\section{Pre-publication history}

The pre-publication history for this paper can be accessed here: http://www.biomedcentral.com/1471-244X/11/50/prepub

doi:10.1186/1471-244X-11-50

Cite this article as: Minelli et al:: The influence of psychiatric screening in healthy populations selection: a new study and meta-analysis of functional 5-HTTLPR and rs 25531 polymorphisms and anxiety-related personality traits. BMC Psychiatry 2011 11:50.

\section{Submit your next manuscript to BioMed Central and take full advantage of:}

- Convenient online submission

- Thorough peer review

- No space constraints or color figure charges

- Immediate publication on acceptance

- Inclusion in PubMed, CAS, Scopus and Google Scholar

- Research which is freely available for redistribution 